\title{
PENGGUNAAN MEDIA AUDIO VISUAL DALAM KEMAMPUAN MEMPRAKTIKKAN BACAAN DAN GERAKAN SHALAT PADA PEMBELAJARAN FIQIH PADA MADRASAH IBTIDAIYAH DARUL ILMI BANJARBARU
}

Oleh:

\author{
Sari Kumala
}

H. Abdul Hafiz

Dosen, UNISKA MAB BANJARMASIN, Kalimantan Selatan Indonesia

Email(sarikumalapgmi@gmail.com),(abdulhafiz.fsiuniska@gmail.com)

\begin{abstract}
Abstrak
Tujuan penelitian ini untuk mengetahui bagaimana Penggunaan Media Audio Visual dalam Kemampuan Mempraktikkan Bacaan dan Gerakan Shalat pada Pembelajaran Fiqih. Subjek penelitian ini adalah peserta didik kelas $\mathrm{V}$ dengan jumlah siswa 27 orang. Metode yang di pakai adalah metode deskriptif kualitatif. Pengumpulan data yang digunakan adalah observasi, teknik tes, yang di analisis dengan menggunakan teknik deskriptif kualitatif. Berdasarkan hasil analisis, peserta didik yang memperoleh nilai di atas KKM sebanyak 23 peserta didik, dengan persentase: $\quad \mathrm{N}=18 / 27 \times 100 \%=67 \%$, sedangkan peserta didik yang Mendapat nilai di bawah KKM sebanyak 9 Peserta didik dengan persentase $\mathrm{N}=9 / 27 \times 100 \%=33 \%$. Jika dilihat pada item setiap aspek dapat disimpulkan bahwa peserta didik masih banyak yang hanya cukup menguasai dalam hal berzikir dan berdo'a sesudah shalat. Sedangkan yang mencapai tingkat menguasai dengan baik adalah pada aspek membaca surah Al Fatihah. Kesimpulannya bahwa Kemampuan
\end{abstract}

Al-Madrasah: Jurnal Ilmiah Pendidikan Madrasah Ibtidaiyah Vol. 3, No. 2, Januari-Juni 2019 
Sari Kumala dan H. Abdul Hafiz: Penggunaan Media Audio Visual dalam Kemampuan Mempraktikkan Bacaan dan Gerakan Shalat pada Pembelajaran Fiqih pada Madrasah Ibtidaiyah Darul Ilmi Banjarbaru

Mempraktikkan Bacaan dan Gerakan Shalat dapat ditingkatkan dengan media audio visual.

Kata Kunci: Media Audio Visual, Bacaan dan Gerakan Shalat

\section{A. Pendahuluan}

Hidup manusia sangat dipengaruhi oleh perkembangan ilmu pengetahuan dan teknologi. Adanya alat-alat itu dapat merubah pikiran manusia, merubah cara kerja dan cara hidupnya. Begitu juga dengan pendidikan tidak lepas dari pengaruh teknlogi (Nasution :2008). Media pembejaran merupakan wahana dan penyampaian informasi atau pesan pembelajaran pada siswa. Dengan adanya media pada proses belajar mengajar, diharapkan dapat membantu guru dalam meningkatkan prestasi belajar pada siswa. Oleh karena itu, guru hendaknya menghadirkan media dalam setiap proses pembelajaran demi tercapainya tujuan pembelajaran. media pendidikan mempunyai kegunaan untuk mengatasi berbagai hambatan, antara lain: hambatan komunikasi, keterbatasan ruang kelas, sikap siswa yang pasif, pengamatan siswa yang kurang seragam, sifat objek belajar yang kurang khusus sehingga tidak memungkinkan dipelajari tanpa media, tempat belajar yang terpencil dan sebagainya.

Materi pelajaran fiqih syarat dengan nilai nilai bagi pembentukan pribadi muslim, namun apabila materi itu disajikan dengan cara yang kurang tepat, tidak mustahil akan timbul pada duru siswa rasa tidak senang terhadap pelajaran fiqih dan bahkan juga terhadap gurunya. Salah satu usaha untuk mengatasi keadaan demikian adalah penerapan media pembelajaran secara terintegrasi dalam proses belajar menagajar.

Sebagai guru fiqih tampaknya dalam mempengaruhi siswa untuk dapat mempelajari dan memahami ajaran Islam sesuai dengan kemampuan nalar manusia terhadap wahyu Allah dan Rasul-Nya perlu dibantu dengan media pembelajaran. Untuk melibatkan sebanyak mungkin alat indra siswa dalam 
Sari Kumala dan H. Abdul Hafiz: Penggunaan Media Audio Visual dalam Kemampuan Mempraktikkan Bacaan dan Gerakan Shalat pada Pembelajaran Fiqih pada Madrasah Ibtidaiyah Darul Ilmi Banjarbaru

proses belajar mengajar maka metode ceramah perlu divariasikan dengan media. Sehingga tujuan pendidikan Islam benar-benar aplikatif muncul kepermukaan. Apalagi sebuah anjuran agama menyatakan dalam Q.S. Al Maidah ayat 16:

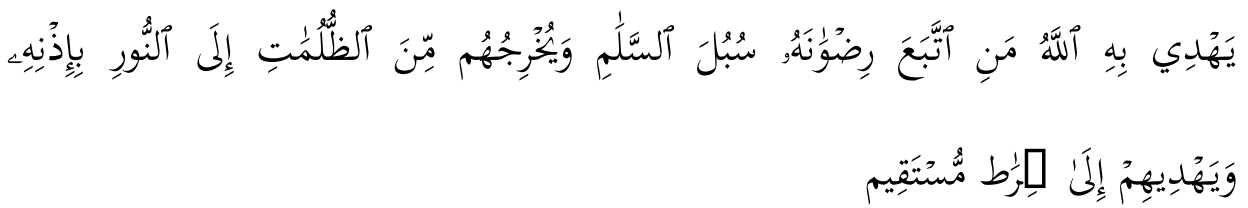

Artinya: (Dengan kitab itu Allah menunjuki orang-orang yang mengikuti keridaan-Nya) maksudnya dengan Alquran dan dengan jalan beriman (ke jalan-jalan keselamatan) jalan yang menyelamatkan mereka (dan mengeluarkan mereka dari kegelapan) yakni kekafiran (kepada cahaya) yakni keimanan (dengan izin-Nya) dengan iradat-Nya (serta membimbing mereka ke jalan yang lurus) yakni agama Islam.

Menggunakan media pembelajaran yang dipersiapkan dengan baik berarti guru telah membantu siswanya mengaktifkan unsur-unsur psikologis yang ada dalam diri mereka seperti pengamatan, daya ingat minat, perhatian, berfikir, fantasi, emosi, dan perkembangan kepribadian mereka. Sikap jiwa mereka yang tenang dengan dengan minat belajar yang besar sangat potensial sekali dibutuh kembangkan sebagai dasar materi keimanan, ibadah, sikap sosial, pembentukan akhlak karimah dan sebagainya (W Gulo : 2002). Pesan-pesan agama yang dibantu dengan media pembelajaran dapat membangkitkan motivasi kegairahan dalam pembelajaran.

Salah satu materi dalam pembelajaran Fiqih adalah tentang shalat, di dalam pembelajaran shalat terdapat gerakan dan bacaan-bacaan shalat yang kadang masih dirasa sulit di praktikkan oleh siswa dengan baik dan benar, maka dengan adanya penggunaan media audio visual dapat membantu kesulitan tersebut serta mampu merangsang kemampuan mereka terhadap materi shalat.

Al-Madrasah: Jurnal Ilmiah Pendidikan Madrasah Ibtidaiyah

Vol. 3, No. 2, Januari-Juni 2019 
Sari Kumala dan H. Abdul Hafiz: Penggunaan Media Audio Visual dalam Kemampuan Mempraktikkan Bacaan dan Gerakan Shalat pada Pembelajaran Fiqih pada Madrasah Ibtidaiyah Darul Ilmi Banjarbaru

\section{B. Metode Penelitian}

1. Lokasi Penelitian

Penelitian ini dilaksanakan di MI Darul Ilmi Banjarbaru, dengan waktu penelitian mulai dari bulan Desember 2018 sampai dengan Mei 2019.

2. Tahapan Penelitian

Data yang diambil adalah data kualitatif, maka deskripsi data ini dilakukan dengan cara menyusun dan mengelompokan data yang ada, sehingga memberikan gambaran terhadap responden. Tujuan penelitian ini merupakan penelitian yang bertujuan untuk mendeskripsikan atau menggambarkan suatu fenomena yang dialami oleh subjek penelitian terhadap objek yang diteliti. Pengumpulan data sangat penting bagi penelitian, sebab teknik pengumpulan data mendukung keberhasilan dalam suatu penelitian.

Penelitian lapangan (field research), penelitian ini dilakukan untuk memperoleh data secara langsung kelapangan melalui :

a. Observasi

Observasi adalah pengamatan langsung kepada suatu objek yang akan diteliti, sedangkan penelitian lapangan adalah usaha pengumpulan data dan informasi secara intensif disertai analisis dan pengujian kembali atas semua yang telah dikumpulkan. Observasi dapat dilakukan dalam suatu waktu yang singkat. Peneliti melakukan pengamatan dengan mengunjungi langsung di Madrasah Ibtidaiyah Darul Ilmi Banjarbaru guna mengetahui langsung keadaan objektif dari sekolah.

b. Teknik tes (tertulis)

Melalui tes ini peserta didik sebagai subjek tes diharuskan memiliki kemampuan mempraktikkan bacaan dan gerakan shalat pada pembelajaran fiqih Ketika peserta didik sudah melihat contoh praktik sholat melalui media audio visual maka, peserta didik dapat mempraktikkan bacaan dan gerakan shalat dengan baik dan benar. Data

Al-Madrasah: Jurnal Ilmiah Pendidikan Madrasah Ibtidaiyah

Vol. 3, No. 2, Januari-Juni 2019 
Sari Kumala dan H. Abdul Hafiz: Penggunaan Media Audio Visual dalam Kemampuan Mempraktikkan Bacaan dan Gerakan Shalat pada Pembelajaran Fiqih pada Madrasah Ibtidaiyah Darul Ilmi Banjarbaru

yang dikumpulkan dalam penelitian iniberupa hasil tes peserta didik. Kompetensi yang akan dicapai oleh peserta didik, peserta didik dapat mempraktikkan bacaan dan gerakan shalat pada pembelajaran fiqih.

3. Instrumen Penilaian

Objek dalam penelitian ini adalah kemampuan mempraktikkan bacaan dan gerakan shalat pada pembelajaran fiqih melalui media audio visual oleh peserta didik, pemilihan metode tersebut akan merangsang kemampuan peserta didik dalam mempraktikkan sholat dengan baik dan benar, peneliti mengambil sampel kelas V yang berjumlah 27 peserta didik. Maka demikian peneliti dapat mengetahui keterampilan peserta didik dalam mempraktikkan shalat di Madrasah Ibtidaiyah Darul Ilmi Banjarbaru.

Observasi dilakukan untuk mengamati pelaksanaan pembelajaran yang sedang dilaksanakan. Untuk melihat perkembangan peserta didik dalam mempraktikkan bacaan dan gerakan shalat pada pembelajaran fiqih, peneliti menggunakan lembar observasi yang digunakan untuk mengemukakan data terkait dengan perkembangan siswa dalam. Selain itu observasi juga dilakukan dengan cara mencatat hal-hal penting pada saat pembelajaran berlangsung.

Setelah observasi dilakukan selanjutnya peneliti menggunakan teknik tes. Teknik tes digunakan untuk mengetahui kemampuan dalam mempraktikkan bacaan dan gerakan shalat pada pembelajaran fiqih, ketika peserta didik melihat tayangan dari media audio visual diharapkan mampu mempraktikkan bacaan dan gerakan shalat dengan baik dan benar, untuk mengetahui apakah media tersebut mampu merangsang kemampuan peserta didik atau tidak. Setelah observasi dan teknik tes Teknik analisis data

Jika data yang ada adalah data kualitatif, maka deskripsi data ini dilakukan dengan cara menyusun dan mengelompokkan data yang ada, sehingga memberikan gambaran nyata terhadap responden. Data kualitatif dilakukan terhadap data yang berupa informasi, uraian dalam bentuk bahasa 
Sari Kumala dan H. Abdul Hafiz: Penggunaan Media Audio Visual dalam Kemampuan Mempraktikkan Bacaan dan Gerakan Shalat pada Pembelajaran Fiqih pada Madrasah Ibtidaiyah Darul Ilmi Banjarbaru

prosa, kemudian dikaitkan dengan data lainnya untuk mendapatkan kejelasan terhadap suatu kebenaran atau sebaliknya sehingga memperoleh gambaran baru ataupun menguatkan gambaran yang sudah ada dan sebaliknya. Jadi, bentuk analisis ini merupakan penjelasan-penjelasan, bukan berupa angka-angka statistik atau bentuk angka lainnya.

Dalam melaksanakan penelitian ini, peneliti melalakukan persiapanpersiapan penelitian diantaranya dengan mengembangkan alat-alat pengumpulan data sesuai dengan tujuan penelitian yang telah ditetapkan, untuk mencari dan mendapatkan data yang dibutuhkan tersebut. Data tersebut dikumpulkan dalam aneka macam cara (observasi, teknik tes, Untuk mengolah data yang terkumpul, peneliti menggunakan teknik data kualitatif sebagai berikut:

1. Analisis data hasil observasi, yaitu data yang diperoleh berdasarkan kunjungan langsung dilokasi penelitian diolah dan dianalisis sehingga diperoleh data yang lebih akurat dan asli, sehingga fakta yang sesungguhnya dapat diungkap secara cermat dan lengkap.

2. Analisis data hasil teknik tes, teknik tes digunakan untuk mengetahui kemampuan dalam mempraktikkan bacaan dan gerakan shalat pada pembelajaran fiqih melalui media audio visual, untuk mengetahui apakah media tersebut mampu merangsang kemampuan peserta didik atau tidak. Data yang terkumpul kemudian dijadikan kesimpulan dari keseluruhan.

Dalam analisis data hasil teknik tes yang menjadi objek penelitian adalah peserta didik kelas V Madrasah Ibtidaiyah Darul Ilmi Banjarbaru yang berjumlah 27 peserta didik. Pemilihan media audio visual tersebut untuk merangsang kemampuan peserta didik dalam mempraktikkan bacaan dan gerakan shalat pada pembelajaran fiqih.

Al-Madrasah: Jurnal Ilmiah Pendidikan Madrasah Ibtidaiyah

Vol. 3, No. 2, Januari-Juni 2019 
Sari Kumala dan H. Abdul Hafiz: Penggunaan Media Audio Visual dalam Kemampuan Mempraktikkan Bacaan dan Gerakan Shalat pada Pembelajaran Fiqih pada Madrasah Ibtidaiyah Darul Ilmi Banjarbaru

Tabel 3.1

Format Penilaian kemampuan mempraktikkan bacaan dan gerakan shalat pada pembelajaran Fiqih

\begin{tabular}{|c|l|l|l|l|l|l|}
\hline No & \multicolumn{1}{|c|}{ Aspek-aspek yang di observasi } & \multicolumn{3}{|c|}{ Skor Nilai } & Ket. \\
\hline & & A & B & C & D & \\
\hline 1. & $\begin{array}{l}\text { Gerakan-gerakan } \\
\text { (Keterampilan ) }\end{array}$ & & & & & \\
\hline a. & Takbiratul Ihram & & & & & \\
\hline b. & Rukuk & & & & & \\
\hline c. & I'tidal & & & & & \\
\hline d. & Sujud & & & & & \\
\hline e. & Duduk antara dua sujud & & & & & \\
\hline f. & Duduk tahiyat awal & & & & & \\
\hline g. & Duduk tahiyat akhir & & & & & \\
\hline h. & Salam & & & & & \\
\hline 2. & Bacaan shalat ( Kognitif ) & & & & \\
\hline a. & Surah Alfatihah & & & & & \\
\hline b. & Surah Pendek & & & & & \\
\hline c. & Bacaan Rukuk & & & & & \\
\hline d. & Bacaan I'tidal & & & & & \\
\hline e. & Bacaan sujud & & & & & \\
\hline f. & Bacaan duduk antara dua sujud & & & & & \\
\hline g. & Bacaan tahiyat & & & & & \\
\hline h. & Bacaan salam & & & & & \\
\hline 3. & Sikap (Afektif) & & & & & \\
\hline a. & Berpakaian rapi ( suci ) & & & & \\
\hline b. & $\begin{array}{l}\text { Berzikir dan berdo'a sesudah } \\
\text { sholat }\end{array}$ & & & & & \\
\hline c. & $\begin{array}{l}\text { Memfokuskan niat shalat hanya } \\
\text { kepada Allah }\end{array}$ & & & & & \\
\hline d. & $\begin{array}{l}\text { Khusu' dan tuma'ninah ( tidak } \\
\text { bergurau dan berhenti sejenak } \\
\text { setelah gerak ) }\end{array}$ & & & & & \\
\hline
\end{tabular}

Keterangan skala nilai:

A : Menguasai dengan baik skor 4

B : Menguasai skor 3

C : Cukup menguasai skor 2

D : Kurang menguasai skor 1

Al-Madrasah: Jurnal Ilmiah Pendidikan Madrasah Ibtidaiyah

Vol. 3, No. 2, Januari-Juni 2019 
Sari Kumala dan H. Abdul Hafiz: Penggunaan Media Audio Visual dalam Kemampuan Mempraktikkan Bacaan dan Gerakan Shalat pada Pembelajaran Fiqih pada Madrasah Ibtidaiyah Darul Ilmi Banjarbaru

Pensekoran :

Jumlah skor yang diperoleh

Persentase $=$

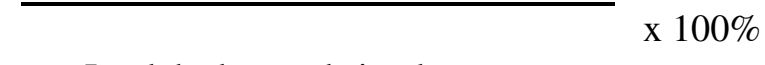

Jumlah skor maksimal

Tabel 3.2

Penentuan Kriteria Dengan Perhitungan Untuk Format Penilaian kemampuan mempraktikkan bacaan dan gerakan shalat pada pembelajaran Fiqih dengan menggunakan media audio visual

\begin{tabular}{|c|c|c|c|}
\hline Interval Presentase & \multicolumn{2}{|c|}{ Nilai Ubahan Skala } & \multirow{2}{*}{ Keterangan } \\
\cline { 2 - 3 } Tingkat Penguasaan & $1-4$ & D-A & \\
\hline $86-100$ & 4 & A & Baik Sekali \\
\hline $76-85$ & 3 & B & Baik \\
\hline $56-75$ & 2 & C & Cukup \\
\hline $10-55$ & 1 & D & Kurang \\
\hline
\end{tabular}

\section{Hasil dan Pembahasan}

a. Deskripsi Data Tes Mempraktikkan Bacaan Dan Gerakan Shalat Dengan Menggunakan Media Audio Visual

Untuk memperoleh data tentang kemampuan dalam mempraktikkan bacaan dan gerakan shalat dengan menggunakan media audio visual, peneliti mengadakan tes kepada peserta didik kelas V di Madrasah Ibtidaiyah Darul Ilmi Banjarbaru pada tanggal 25 April 2019.

Berdasarkan aspek aspek yang di observasi pada penilaian kemampuan mempraktikkan bacaan dan gerakan shalat dengan menggunakan media audio visual pada peserta didik di Madrasah Ibtidaiyah Darul Ilmi Banjarbaru kelas $\mathrm{V}$ diperoleh analisis sebagai berikut :

1) Aspek takbiratul ihram : Pada gerakan (Keterampilan ) pada poin takbiratul ihram menguasai sebanyak 22 orang dan menguasai dengan baik sebanyak 5 orang. Jadi pada poin ini kebanyakan siswa menguasai 
Sari Kumala dan H. Abdul Hafiz: Penggunaan Media Audio Visual dalam Kemampuan Mempraktikkan Bacaan dan Gerakan Shalat pada Pembelajaran Fiqih pada Madrasah Ibtidaiyah Darul Ilmi Banjarbaru

dengan mengangkat tangan dan mengucap takbir serta pandangan ketempat sujud.

2) Aspek rukuk : Pada gerakan rukuk menguasai sebanyak 19 orang dan menguasai dengan baik sebanyak 8 orang. Pada poin ini siswa sudah menguasai bagaimana cara ruku yang benar dengan posisi membungkukkan badan, belakang sejajar serta pandangan ketempat sujud dan kedua tangan menggenggam kedua lutut.

3) Aspek I'itidal : Perolehan pada gerakan i'itidal cukup menguasai sebanyak 8 orang, menguasai 15 orang dan menguasai dengan baik sebanyak 4 orang. Pada aspek ini sebagian peserta didik masih ada yang melakukan gerakan-gerakan tangan sehingga tidak tuma'ninah.

4) Aspek sujud : Pada gerakan sujud cukup menguasai ada 7 orang, menguasai 12 orang dan menguasai dengan baik sebanyak 8 orang. Pada aspek ini sebagian peserta didik masih ada yang menggerakgerakkan kakinya pada saat sujud.

5) Aspek duduk antara dua sujud : perolehan pada aspek ini adalah cukup menguasai 5 orang, menguasai 16 orang dan menguasai dengan baik 6 orang. Pada aspek ini ada beberapa yang masih cara duduknya sdkit perlu diperbaiki.

6) Aspek duduk tahiyat awal : pada aspek ini kurang menguasai ada 3 orang, menguasai 20 orang dan menguasai dengan baik ada 4 orang. Pada aspek ini siswa sudah banyak yang menguasai hanya saja ada beberapa yang masih kurang pada posisi kaki pada saat duduk masih ada sedikit yang perlu diperbaiki.

7) Aspek duduk tahiyat akhir : pada aspek ini ada yang cukup menguasai yaitu sebanyak 5 orang, menguasai 19 orang dan menguasai dengan baik sebanyak 3 orang, pada aspek ini masih ada yang sedikit diperbaiki pada bagian kaki tapi duduk nya sudah benar.

8) Aspek salam : pada aspek ini cukup menguasai 2 orang, menguasai 16 orang dan menguasai dengan baik 9 orang.

Al-Madrasah: Jurnal Ilmiah Pendidikan Madrasah Ibtidaiyah

Vol. 3, No. 2, Januari-Juni 2019 
Sari Kumala dan H. Abdul Hafiz: Penggunaan Media Audio Visual dalam Kemampuan Mempraktikkan Bacaan dan Gerakan Shalat pada Pembelajaran Fiqih pada Madrasah Ibtidaiyah Darul Ilmi Banjarbaru

9) Aspek Bacaan Surah Alfatihah : pada aspek ini menguasai 10 orang dan 17 orang menguasai dengan baik, maka pada aspek ini dari segi bacaan siswa sudah banyak menguasai dengan baik dan benar.

10) Aspek bacaan surah pendek : pada aspek ini menguasai 14 orang dan menguasai dengan baik sebanyak 13 orang, maka pada aspek membaca hncfkuijiju,ophysurah pendek ini pun hamper sama dengan aspek membaca surah Al Fatihah siswa sudah banyak yang menguasai dengan baik.

11) Aspek bacaan rukuk: pada aspek ini menguasai sebanyak 18 orang dan menguasai dengan baik 9 orang maka pada aspek bacaan rukuk ini siswa sudah banyak yang menguasai bacaan rukuk dengan baik.

12) Aspek bacaan I'itidal : pada aspek ini menguasai sebanyak 18 orang dan menguasai dengan baik 9 orang maka pada aspek ini siswa sudah banyak yang menguasai bacaan rukuk dengan baik.

13) Aspek bacaan sujud: pada aspek ini cukup menguasai 1 orang, menguasai 18 orang dan menguasai dengan baik 8 orang maka pada aspek pun siswa sudah banyak yang menguasai bacaan sujud walaupun ada 1 yang masih cukup menguasai yang mana perlu ada perbaikan sedikit.

14) Aspek bacaan duduk antara dua sujud: pada aspek ini cukup menguasai 1 orang, menguasai 24 orang dan menguasai dengan baik 2 orang maka pada aspek pun siswa sudah banyak yang menguasai bacaan duduk antara dua sujud walaupun ada 1 yang masih cukup menguasai yang mana perlu ada perbaikan sedikit.

15) Aspek bacaan tahiyat : pada aspek ini cukup menguasai ada 6 orang, menguasai 21 orang, maka pada aspek ini kebanyakan sudah menguasai tapi masih ada beberapa orang yang pada saat membaca masih perlu sedikit perbaikan bacaan dan belul ada yang menguasai dengan baik membaca tahiyat.

Al-Madrasah: Jurnal Ilmiah Pendidikan Madrasah Ibtidaiyah

Vol. 3, No. 2, Januari-Juni 2019 
Sari Kumala dan H. Abdul Hafiz: Penggunaan Media Audio Visual dalam Kemampuan Mempraktikkan Bacaan dan Gerakan Shalat pada Pembelajaran Fiqih pada Madrasah Ibtidaiyah Darul Ilmi Banjarbaru

16) Aspek bacaan salam : pada aspek ini cukup menguasai 2 orang, menguasai 20 orang dan menguasai dengan baik 5 orang, maka pada aspek ini sudah banyak yang menguasai dan ada beberapa yang masih sedikit perlu perbaikan pada saat melafalkan bacaan salam.

17) Aspek sikap berpakain rapi : pada aspek ini cukup menguasai 2 orang dan menguasai 25 orang maka pada aspek ini perserta didik sudah mengetahui bahwa ketika melaksanakan shalat menggunakan pakaian yang rapi artinya suci dari.

18) Aspek berzikir dan berdo'a sesudah shalat : pada aspek ini cukup menguasai 12 orang dan menguasai 15 orang, maka pada aspek ini juga sudah banyak yang menguasai berzikir dan berdo'a walaupun sebagian masih dalam tingkatan cukup menguasai.

19) Aspek memfokuskan niat shalat hanya kepada Allah : pada aspek ini cukup menguasai 4 orang dan menguasai 23 orang, maka pada aspek ini kebanyakan siswa sudah mulai memfokuskan niat sholat hanya kepada Allah.

20) Aspek Khusu' dan tuma'ninah ( tidak bergurau dan berhenti sejenak setelah gerak ) : pada aspek ini siswa yang cukup menguasai ada 7 orang, menguasai 18 orang dan menguasai dengan baik ada 2 orang, maka pada aspek ini banyak siswa yang sudah mengetahui bagaimana khusu' dalam sholat dan tuma' ninah setiap setelah melakukan gerakangerakan didalam sholat. Walaupun masih ada beberapa orang yang cukup menguasai karena mereka masih ada yang sebagian gerakan tidak bertuma'ninah.

Berikut penyajian skor peserta didik dalam mempraktikkan bacaan dan gerakan shalat pada 3 kriteria penilaian dari gerakan bacaan dan sikap siswa. 
Sari Kumala dan H. Abdul Hafiz: Penggunaan Media Audio Visual dalam Kemampuan Mempraktikkan Bacaan dan Gerakan Shalat pada Pembelajaran Fiqih pada Madrasah Ibtidaiyah Darul Ilmi Banjarbaru

Tabel 3.1. Hasil Perolehan Nilai Peserta Didik Mempraktikkan Bacaan dan Gerakan Shalat

\begin{tabular}{|c|c|c|c|c|c|c|c|c|c|c|c|c|c|c|c|c|c|c|c|c|c|c|c|}
\hline \multirow[t]{2}{*}{ No } & \multirow[t]{2}{*}{ Nama siswa } & \multicolumn{8}{|c|}{ 1. $\begin{array}{l}\text { Gerakan Shalat } \\
\text { (keterampilan) }\end{array}$} & \multicolumn{8}{|c|}{\begin{tabular}{|ll}
2. & Bacaan \\
& shalat(Kognitif) \\
\end{tabular}} & \multicolumn{4}{|c|}{$\begin{array}{l}\text { 3. Sikap } \\
\text { (Afektif ) }\end{array}$} & \multirow{2}{*}{$\begin{array}{l}\text { Juml } \\
\text { ah } \\
\text { nilai }\end{array}$} & \multirow[t]{2}{*}{ Ket. } \\
\hline & & $\mathrm{a}$ & $\mathrm{B}$ & $\mathrm{c}$ & $\mathrm{D}$ & $\mathrm{e}$ & $\mathrm{F}$ & $\mathrm{G}$ & $\mathrm{H}$ & $\mathrm{a}$ & $\mathrm{b}$ & $\mathrm{c}$ & $\mathrm{d}$ & $\mathrm{E}$ & $\mathrm{f}$ & $\mathrm{g}$ & $\mathrm{h}$ & $\mathrm{a}$ & $\mathrm{b}$ & $\mathrm{c}$ & $\mathrm{d}$ & & \\
\hline 1 & A.Akmal Yuda & 3 & 4 & 3 & 3 & 4 & 4 & 4 & 4 & 4 & 4 & 3 & 3 & 3 & 3 & 2 & 3 & 2 & 2 & 3 & 3 & 80 & Baik \\
\hline 2 & A.Hafiz B & 3 & 3 & 2 & 2 & 2 & 3 & 2 & 3 & 3 & 3 & 3 & 3 & 3 & 3 & 3 & 2 & 2 & 2 & 3 & 2 & 65 & cukup \\
\hline 3 & A.Zainul M & 3 & 3 & 2 & 3 & 3 & 2 & 3 & 3 & 3 & 3 & 3 & 3 & 3 & 3 & 2 & 3 & 3 & 2 & 3 & 3 & 70 & cukup \\
\hline 4 & Alfina R. & 4 & 4 & 4 & 4 & 4 & 3 & 3 & 3 & 3 & 3 & 4 & 4 & 4 & 4 & 3 & 3 & 3 & 3 & 3 & 3 & 86 & $\begin{array}{l}\text { Baik } \\
\text { sekali }\end{array}$ \\
\hline 5 & Daffa Restu & 3 & 3 & 3 & 3 & 4 & 4 & 4 & 4 & 4 & 3 & 4 & 4 & 4 & 3 & 3 & 3 & 3 & 3 & 3 & 3 & 87 & $\begin{array}{l}\text { Baik } \\
\text { sekali }\end{array}$ \\
\hline 6 & Della Safitri & 3 & 3 & 2 & 2 & 2 & 3 & 3 & 3 & 4 & 4 & 3 & 3 & 3 & 3 & 2 & 2 & 3 & 2 & 3 & 2 & 72 & Cukup \\
\hline 7 & M.Fakhruzzani & 3 & 3 & 4 & 4 & 3 & 3 & 3 & 3 & 4 & 3 & 3 & 3 & 2 & 3 & 3 & 3 & 3 & 2 & 3 & 3 & 76 & Baik \\
\hline 8 & M.Catur Z. & 3 & 3 & 2 & 2 & 3 & 3 & 2 & 2 & 3 & 3 & 3 & 3 & 3 & 3 & 3 & 3 & 3 & 3 & 3 & 3 & 70 & Cukup \\
\hline 9 & M.Dhafin S. & 4 & 4 & 4 & 3 & 3 & 3 & 3 & 3 & 3 & 3 & 3 & 4 & 4 & 4 & 3 & 3 & 3 & 3 & 3 & 3 & 82 & Baik \\
\hline 10 & M.Erlangga & 3 & 3 & 3 & 2 & 2 & 3 & 3 & 3 & 4 & 4 & 3 & 3 & 3 & 3 & 3 & 3 & 3 & 2 & 2 & 2 & 71 & Cukup \\
\hline 11 & M.Hafiz A. & 3 & 3 & 3 & 4 & 3 & 3 & 2 & 3 & 4 & 4 & 3 & 3 & 3 & 3 & 3 & 3 & 3 & 3 & 2 & 3 & 76 & Baik \\
\hline 12 & M.Hamid B. & 3 & 4 & 4 & 4 & 4 & 3 & 3 & 3 & 4 & 4 & 4 & 4 & 4 & 3 & 3 & 3 & 3 & 3 & 3 & 3 & 86 & $\begin{array}{l}\text { Baik } \\
\text { sekali }\end{array}$ \\
\hline 13 & M.Ikhsanuddin & 3 & 3 & 3 & 3 & 3 & 3 & 3 & 4 & 4 & 3 & 4 & 4 & 3 & 3 & 3 & 3 & 3 & 3 & 3 & 3 & 80 & Baik \\
\hline 14 & M.Iqbal R & 3 & 3 & 2 & 2 & 3 & 3 & 3 & 3 & 4 & 4 & 3 & 3 & 3 & 3 & 3 & 3 & 3 & 2 & 3 & 2 & 72 & Cukup \\
\hline 15 & M.Ridho S. & 3 & 3 & 3 & 3 & 3 & 3 & 3 & 4 & 4 & 4 & 3 & 3 & 3 & 3 & 3 & 3 & 3 & 3 & 3 & 3 & 78 & Baik \\
\hline 16 & M.Zaini & 4 & 4 & 3 & 3 & 3 & 3 & 3 & 3 & 4 & 4 & 4 & 4 & 4 & 3 & 3 & 3 & 3 & 3 & 3 & 3 & 83 & Baik \\
\hline
\end{tabular}

Al-Madrasah: Jurnal Ilmiah Pendidikan Madrasah Ibtidaiyah Vol. 3, No. 2, Januari-Juni 2019 
Sari Kumala dan H. Abdul Hafiz: Penggunaan Media Audio Visual dalam Kemampuan Mempraktikkan Bacaan dan Gerakan Shalat pada Pembelajaran Fiqih pada Madrasah Ibtidaiyah Darul Ilmi Banjarbaru

\begin{tabular}{|l|l|l|l|l|l|l|l|l|l|l|l|l|l|l|l|l|l|l|l|l|l|l|l|}
\hline 17 & Nadia R. & 3 & 3 & 3 & 4 & 4 & 4 & 3 & 3 & 4 & 4 & 4 & 4 & 4 & 3 & 3 & 4 & 3 & 3 & 3 & 4 & 87 & $\begin{array}{l}\text { Baik } \\
\text { sekali }\end{array}$ \\
\hline 18 & Nanda N.R & 3 & 3 & 3 & 3 & 3 & 3 & 3 & 4 & 4 & 3 & 4 & 3 & 3 & 3 & 3 & 4 & 3 & 3 & 3 & 3 & 80 & Baik \\
\hline 19 & Nazwa A. & 4 & 4 & 3 & 4 & 3 & 3 & 3 & 3 & 4 & 4 & 3 & 3 & 3 & 3 & 2 & 3 & 3 & 2 & 3 & 3 & 78 & Baik \\
\hline 20 & Nidaul H. & 3 & 3 & 3 & 2 & 2 & 2 & 2 & 3 & 3 & 3 & 3 & 3 & 3 & 2 & 3 & 3 & 3 & 2 & 2 & 2 & 65 & Cukup \\
\hline 21 & Novita Sari & 3 & 4 & 3 & 3 & 3 & 4 & 4 & 4 & 4 & 4 & 3 & 3 & 3 & 3 & 3 & 4 & 3 & 3 & 3 & 3 & 83 & Baik \\
\hline 22 & Nuriani & 3 & 3 & 2 & 2 & 2 & 2 & 2 & 3 & 3 & 3 & 3 & 3 & 3 & 3 & 2 & 3 & 3 & 2 & 2 & 2 & 63 & Cukup \\
\hline 23 & N.Mufattahah & 3 & 3 & 2 & 3 & 3 & 3 & 3 & 2 & 3 & 3 & 3 & 3 & 3 & 3 & 2 & 3 & 3 & 2 & 3 & 2 & 68 & cukup \\
\hline 24 & Talita S. & 3 & 3 & 3 & 3 & 3 & 3 & 3 & 3 & 4 & 3 & 3 & 3 & 3 & 3 & 3 & 3 & 3 & 3 & 3 & 3 & 76 & baik \\
\hline 25 & Zulfikar B & 3 & 3 & 3 & 4 & 4 & 3 & 3 & 4 & 3 & 3 & 4 & 4 & 4 & 3 & 3 & 4 & 3 & 3 & 3 & 4 & 85 & baik \\
\hline 26 & Naila A. & 3 & 3 & 2 & 3 & 3 & 3 & 3 & 4 & 4 & 4 & 3 & 3 & 3 & 3 & 3 & 3 & 3 & 2 & 3 & 3 & 76 & baik \\
\hline 27 & Annisa D. & 4 & 4 & 3 & 4 & 3 & 3 & 3 & 4 & 3 & 4 & 4 & 4 & 4 & 3 & 3 & 4 & 3 & 3 & 3 & 3 & 86 & $\begin{array}{l}\text { Baik } \\
\text { sekali }\end{array}$ \\
\hline
\end{tabular}

Al-Madrasah: Jurnal Ilmiah Pendidikan Madrasah Ibtidaiyah Vol. 3, No. 2, Januari-Juni 2019 
Sari Kumala dan H. Abdul Hafiz: Penggunaan Media Audio Visual dalam Kemampuan Mempraktikkan Bacaan dan Gerakan Shalat pada Pembelajaran Fiqih pada Madrasah Ibtidaiyah Darul Ilmi Banjarbaru

\section{b. Hasil analisis data}

Nilai KKM yang harus di capai oleh peserta didik di kelas V adalah 75. Penggunaan media audio visual sangat membantu dalam proses pembelajaran fiqih khususnya saat pembelajaran shalat, dengan adanya media tersebut peserta didik dapat meningkatkan kemampuan mempraktikkan bacaan dan gerakan shalat, hal ini terlihat dari nilai peserta didik, nilai peserta didik sebagian besar di atas nilai KKM, sedangkan mempraktikkan bacaan dan gerakan shalat tanpa media audio visual banyak peserta didik yang mendapatkan nilai di bawah KKM.

Berdasarkan hasil analisis, peserta didik yang memperoleh nilai di atas KKM sebanyak 18 orang dari 27 orang peserta didik, dengan persentase yang dihitung dengan rumus sebagai berikut : $\mathrm{N}=18 / 27 \times 100 \%=67 \%$ dari 27 peserta didik. Sedangkan, peserta didik yang mendapat nilai dibawah KKM (75) sebanyak 9 peserta didik, dengan persentase yang dihitung dengan rumus sebagai berikut : $\mathrm{N}=9 / 27 \times 100 \%=33 \%$ dari 20 pserta didik.

\section{Kesimpulan}

Secara umum kemampuan peserta didik Madrasah Ibtidaiyah Darul Ilmi Banjarbaru dalam mempraktikkan bacaan dan gerakan shalat dapat dikatakan baik dari sebelumnya. Hal tersebut dapat dilihat dari hasil penelitian serta penggunaan media audio visual dapat meningkatkan kemampuan dalam membaca bacaan shalat serta mempraktikkan gerak shalat karena media audio visual berupa video tersebut menampilkan tata cara shalat lengkap dengan bacaan dan gerakan-gerakan shalat sehingga merangsang pendengaran dan penglihatan anak. Jika dilihat pada item setiap aspek dapat disimpulkan bahwa peserta didik masih banyak yang hanya cukup menguasai dalam hal berzikir dan berdo'a sesudah shalat. Sedangkan yang mencapai tingkat menguasai dengan baik adalah pada aspek membaca surah Al Fatihah. 
Sari Kumala dan H. Abdul Hafiz: Penggunaan Media Audio Visual dalam Kemampuan Mempraktikkan Bacaan dan Gerakan Shalat pada Pembelajaran Fiqih pada Madrasah Ibtidaiyah Darul Ilmi Banjarbaru

\section{E. Saran dan Rekomendasi}

Berdasarkan penelitian yang telah peneliti lakukan, ada beberapa saran untuk meningkatkan kemampuan mempraktikkan bacaan dan gerakan shalat pada siswa maka:

1. Kepada pihak sekolah hendaknya menyiapkan media seperti LCD guna mendukungnya proses pembelajaran dan member pengetahuan kepada guru bagaiamana cara menggunakan media tesebut

2. Kepada Guru mata pelajaran Fiqih, bisa mengembangkan lagi media audio visual pada materi lain sehingga pembelajaran tidak membosankan karena dengan adanya media audio visual bisa meningkatkan daya rangsang pendengaran dan penglihatan anak.

Al-Madrasah: Jurnal Ilmiah Pendidikan Madrasah Ibtidaiyah

Vol. 3, No. 2, Januari-Juni 2019 
Sari Kumala dan H. Abdul Hafiz: Penggunaan Media Audio Visual dalam Kemampuan Mempraktikkan Bacaan dan Gerakan Shalat pada Pembelajaran Fiqih pada Madrasah Ibtidaiyah Darul Ilmi Banjarbaru

\section{Daftar Pustaka}

Afninti Loka Puspita, “Telaah Kurikulum Fiqh Madrasah Ibtidaiyah", http//varossita.blogspot.com/2010/10/html, diakses pada 24 September 2018

AH sanaky, Hujair, Media Pembelajaran, Yogyakarta: Safiria Insania Press, 2009.

Ainurrahman, Belajar dan Pembelajaran. Bandung: CV. Alfabeta, 2012.

Asnawir, M. basyiruddin Usman. Media Pembelajaran. Jakarta: Ciputat Pers, 2002

Bakhrul Ulum, "Mata Pelajaran Fiqih", http//blogeulum.blogspot.com/24/2/2013/html, diakses pada 24 September 2018

Chaeruddin, Media Membantu Mempertinggi Mutu Proses Belajar, Jakarta: Buletin Pusat Perbukuan, Departemen Pendidikan Nasional, 2004.

Fathurrohman, Pupuh, dan M.Sobry Sutikno. Strategi Belajar Mengajar. Bandung: PT. Refika Aditama, 2011.

Hadi Miarso, Yusuf, Menyamai Benih Teknologi Pendidikan, Jakarta: Kencana,2007

Hanafiah, nanang dan Cucu Suhana. Konsep Strategi Pembelajaran. Bandung: PT. Refika Aditama, 2009.

Hasanah, Aan. Pengembangan Profesi Keguruan, Pustaka Setia: Bandung, 2012.

Nasution, Teknologi Pendidikan. Jakarta: Bumi Aksara, 2008.

Sanjaya, Wina. Strategi Pembelajaran; Berorentasi setandar Proses Pendidikan, Jakarta: Kencana Prenada Media Group, 2008.

Suyono dan Hariyanto. Belajar dan Pembelajaran. Bandung: PT. Remaja Rosdakarya, 2011.

Al-Madrasah: Jurnal Ilmiah Pendidikan Madrasah Ibtidaiyah Vol. 3, No. 2, Januari-Juni 2019 
Sari Kumala dan H. Abdul Hafiz: Penggunaan Media Audio Visual dalam Kemampuan Mempraktikkan Bacaan dan Gerakan Shalat pada Pembelajaran Fiqih pada Madrasah Ibtidaiyah Darul Ilmi Banjarbaru

Syah, Muhibbin. Psikologi Belajar. Jakarta: Raja Grafindo Persada, 2008.

W Gulo. Strategi Belajar Mengajar. Jakarta: Gramedia Widiasarana Indonesia, 2002.

Al-Madrasah: Jurnal Ilmiah Pendidikan Madrasah Ibtidaiyah

Vol. 3, No. 2, Januari-Juni 2019 
Sari Kumala dan H. Abdul Hafiz: Penggunaan Media Audio Visual dalam Kemampuan Mempraktikkan Bacaan dan Gerakan Shalat pada Pembelajaran Fiqih pada Madrasah Ibtidaiyah Darul Ilmi Banjarbaru

Al-Madrasah: Jurnal Ilmiah Pendidikan Madrasah Ibtidaiyah

Vol. 3, No. 2, Januari-Juni 2019 